\title{
ANALISIS RASIO KEUANGAN UNTUK MEMPREDIKSI KONDISI FINANCIAL DISTRESS PERUSAHAAN MANUFAKTUR YANG TERDAFTAR DI BEI
}

\author{
Sulistyani \\ yayasulistyani@gmail.com \\ Universitas Ahmad Dahlan \\ Deni Ismanto \\ denoxis@yahoo.com \\ Universitas Ahmad Dahlan
}

\begin{abstract}
ABSTRAK
Financial distress precedes bankruptcy. Most financial distress models actually rely on bankruptcy data, which is easier to obtain. The purpose of this research to examine financial ratios that predict financial distress condition of a firm. The sample of this research consist of 14 distress firm and 79 non-distress firms, chosen by purposive sampling. The statistic method which is used to test on the research hypothesis is logistic regresion. The results show that the liquidity ratio (current assets/current liabilities) and a leverage ratio (current leabilities/total asset) is a significant variable to determine of financial distress firms. When profitability ratio (net income/net sales) and price earning ratio (market price per share/earnings per share) are not significant variables to determine of financial distress.
\end{abstract}

Keywords: Financial Distress; Financial Ratios; Bankruptcy.

\begin{tabular}{l}
\hline \multicolumn{4}{c}{ PENDAHULUAN } \\
Perkembangan ekonomi dunia \\
dalam beberapa tahun terakhir telah \\
mengalami kemajuan yang sangat pesat. \\
Kemajuan yang sangat pesat ini \\
disebabkan oleh semakin kuat dan \\
meluasnya globalisasi di seluruh dunia. \\
Bisnis yang kuat dan berpengalaman \\
akan semakin mendapat keuntungan \\
akan meluasnya pengaruh globalisasi. \\
Akan tetapi di sisi lain, sebagai bisnis yang \\
baru tumbuh ataupun bisnis yang \\
berskala nasional akan sulit untuk \\
bersaing dengan perusahaan asing, \\
sehingga dampaknya adalah perusahaan \\
yang berskala kecil akan mengalami \\
krisis keuangan dalam perusahaan \\
mereka.
\end{tabular}

Tingkat kesehatan perusahaan dapat dinilai dari beberapa indikator utama yang digunakan adalah laporan keuangan perusahaan yang bersangkutan.
Mereka yang berkepentingan terhadap pengembangan perusahaan sangatlah perlu untuk mengetahui kondisi keuangan perusahaan tersebut dan hal tersebut tercermin dalam laporan neraca, laporan laba rugi, serta laporan-laporan lain (Fraser, 2008).

Laporan keuangan digunakan sebagai alat ukur keberhasilan suatu perusahaan dalam menjalankan kegiatan bisnisnya. Tingkat kesehatan perusahaan sangat penting untuk meningkatkan efisiensi dan meningkatkan efektifitas dalam menjalankan bisnis sehingga kemampuan perusahaan dalam meningkatkan profit dapat ditingkatkan. Berdasarkan laporan keuangan tersebut akan dapat di analisa dan dihitung sejauh rasio keuangan yang lazim digunakan sebagai dasar penilaian kesehatan perusahaan. Hasil analisis laporan keuangan akan membantu menginterpretasikan berbagai hubungan 
serta kecenderungan yang dapat memberikan dasar pertimbangan mengenai potensi keberhasilan perusahaan dimasa yang akan datang (Fraster, 2008).

Laporan keuangan yang diterbitkan oleh perusahaan merupakan salah satu sumber informasi mengenai posisi keuangan perusahaan, kinerja serta perubahan posisi keuangan perusahaan yang sangat berguna untuk mendukung pengambilan keputusan yang tepat. Agar informasi yang tersaji menjadi lebih bermanfaat dalam pengambilan keputusan, data keuangan harus dikonversi menjadi informasi yang berguna dalam pengambilan keputusan yang ekonomis. Hal ini ditempuh dengan cara melakukan analisis laporan keuangan. Model yang sering digunakan dalam melakukan analisis tersebut adalah dalam bentuk rasio-rasio keuangan (Munawir, 2002).

Untuk dapat memahami informasi keuangan tersebut diperlukan analisa laporan keuangan yang meliputi perhitungan dan interpretasi rasio keuangan. Rasio yang dimaksud adalah suatu angka yang menunjukkan hubungan antara unsur yang satu dengan unsur yang lainnya dalam laporan keuangan. Rasio menggambarkan suatu hubungan atau perimbangan (Mathematical Relationship) antara suatu jumlah tertentu dengan jumlah yang lain, dan dengan menggunakan alat analisis b erupa rasio ini akan dapat menjelaskan atau memberikan gambaran kepada penganalisa tentang baik buruknya keadaan atau posisi keuangan suatu perusahaan terutama apabila angka rasio tersebut dibandingkan dengan angka rasio pembanding yang digunakan sebagai standar (Munawir, 2002). Dengan menggunakan analisa rasio dimungkinkan untuk dapat menentukan tingkat likuiditas, solvabilitas, dan profitabilitas perusahaan. Rasio/indikator keuangan sebagai hasil analisa terhadap laporan keuangan dapat dijadikan sarana untuk semua elemen/unsur laporan keuangan, tergantung tujuan dan kepentingan pemakai.

Lebih lanjut, rasio keuangan merupakan ukuran pengganti dalam mengobservasi karakteristik sebenarnya dari suatu perusahaan. Secara umum, rasio yang mengukur profitabilitas, likuidasi, dan solvabilitas telah berhasil menunjukkan keberhasilan sebagai indikator akan terjadinya kebangkrutan perusahaan atau lebih dikenal dengan financial distress. (Foster, 1986) dalam Almalia (2003) menyatakan empat hal yang mendorong analisis laporan keuangan dilakukan dengan model rasio keuangan yaitu :

1. Untuk mengendalikan pengaruh perbedaan besaran antar perusahaan atau antar waktu.

2. Untuk membuat data lebih memenuhi asumsi alat statistik yang digunakan.

3. Untuk menginvestigasi teori yang terkait dengan rasio keuangan.

4. Untuk mengkaji hubungan empirik antara rasio keuangan dan estimasi atau prediksi variabel tertentu (seperti kebangkrutan atau financial distress).

Fenomena-fenomena kegagalan perusahaan sebenarnya dapat dicermati melalui analisis laporan keuangan yang menggunakan teknik analisis rasio-rasio keuangan. Jelas, rasio-rasio tersebut bisa dimanfaatkan untuk memprediksi kejadian yang akan datang dengan menghubungkan rasiorasio keuangan dengan fenomena ekonomi. Hanya ada masalah dalam penggunaan rasio-rasio tadi, rasio keuangan sangat banyak macamnya dan sangat variatif (Suroso, 2006).

Jadi sulit memastikan rasio-rasio apa saja yang paling dominan untuk mempengaruhi kondisi kegagalan perusahaan. Ada dua macam kegagalan yaitu kegagalan ekonomi dan kegagalan keuangan (Suroso, 2006). Kegagalan ekonomi suatu perusahaan dikaitkan dengan keseimbangan antara pendapatan dengan pengeluaran. Kegagalan ekonomi juga bisa disebabkan oleh biaya modal 
perusahaan yang lebih besar dari tingkat laba atas biaya historis investasi. Sementara itu, sebuah perusahaan dikatakan gagal keuangannya jika perusahaan tersebut tidak mampu membayar kewajibannya pada waktu jatuh tempo, meskipun aktiva total melebihi kewajibannya. Keadaan ini sering didefinisikan sebagai insolvensi teknis (tehnical insolvensi) menurut Hanifah (2013) dalam Arif (2013). Tentu saja, sebuah perusahaan juga akan dinyatakan pailit jika total kewajibannya melebihi nilai wajar dari aktiva totalnya.

Tingkat kesehatan penting artinya bagi perusahaan untuk meningkatkan efisiensi dalam menjalankan usahanya, sehingga kemampuan untuk memperoleh keuntungan dapat ditingkatkan dan untuk menghindari adanya potensi kebangkrutan. Selain itu dengan analisis tingkat kesehatan keuangan, maka akan dapat dinilai kemampuan perusahaan untuk memenuhi kewajiban-kewajiban jangka pendeknya, stuktur modal perusahaan, distribusi aktivanya, keefektifan penggunaan aktivanya, hasil usaha atau pendapatan yang telah dicapai beban-beban tetap yang harus dibayar serta memprediksi potensi kebangkrutan yang akan dicapai (Brahmana, 2007 dalam Arif, 2013). Salah satu pentingnya analisis terhadap laporan keuangan adalah untuk meramalkan kontinuitas atas kelangsungan hidup perusahaan dan financial distress.

Finansial distress terjadi sebelum kebangkrutan. Model financial distress perlu untuk dikembangkan, karena dengan mengetahui kondisi financial distress perusahaan sejak dini diharapkan dapat dilakukan tindakantindakan untuk mengantisipasi kondisi yang mengarah pada kebangkrutan (Almalia, 2006). Tingkat kesehatan dan potensi kebangkrutan dapat diketahui dengan menganalisa laporan keuangan yang diterbitkan. Laporan keuangan merupakan alat yang sangat penting untuk memperoleh informasi yang berkaitan dengan posisi keuangan dan hasil-hasil yang sudah dicapai terhadap strategi yang telah diterapkan oleh perusahaan. Dengan melakukan analisis laporan keuangan maka pimpinan perusahaan dapat mengetahui keadaan serta pengembangan kondisi finansial serta hasil-hasil yang telah dicapai di masa sekarang. Selain itu dengan menganalisa laporan keuangan dapat diketahui kelemahan-kelemahan serta kemajuan yang telah diperoleh yang akan dijadikan pedoman untuk masa yang akan dating (Platt, 2002).

Banyak sekali literatur yang menggambarkan model prediksi kebangkrutan perusahaan, tetapi hanya sedikit penelitian yang berusaha untuk memprediksi financial distress perusahaan. Hal ini dikarenakan sangat sulit mendefinisikan secara objektif permulaan adanya financial distress. Rasio analisis tradisional berfokus pada profitabilitas, solvabilitas, dan likuiditas

(Hanafi, 2004). Perusahaan yang mengalami kerugian, tidak dapat membayar kewajiban atau tidak likuid mungkin memerlukan restrukturisasi. Untuk mengetahui adanya gejala akan terjadinya kebangkrutan, diperlukan suatu model untuk memprediksi financial distress guna menghindari kerugian dalam nilai investasi (Platt, 2002). Untuk membuktikan bahwa laporan keuangan bermanfaat maka dilakukan penelitian mengenai manfaat laporan keuangan. Salah satu bentuk penelitian yang dilakukan yang menggunakan rasio keuangan yaitu penelitian yang berkaitan dengan manfaat laporan keuangan untuk tujuan memeprediksikan kinerja perusahaan seperti kebangkrutan dan financial distress.

Kebangkrutan adalah kesulitan keuangan yang sangat parah sehingga perusahaan tidak mampu untuk menjalankan operasi perusahaan dengan baik. Sedangkan financial distress adalah kesulitan keuangan atau likuidasi yang mungkin sebagai awal kebangkrutan (Ardina, 2013). Prediksi kebangkrutan 
akibat kesulitan keuangan masih jarang dilakukan, karena sulitnya mencari data keuangan perusahaan di Indonesia dan atau disebabkan kebangkrutan yang di publikasikan. Analisis kesulitan keuangan akan sangat membantu pembuatan keputusan untuk menentukan sikap terhadap perusahaan yang mengalami kesulitan keuangan. Oleh karena itu, perlu dicari model tentang petunjuk adanya perusahaan yang mengalami kesulitan keuangan atau financial distress dan mungkin akan mengalami kebangkrutan.

Tujuan dari penelitian ini di antaranya:

1. Untuk menganalisis semakin tinggi rasio likuiditas, akan memungkinkan perusahaan untuk mengalami financial distress semakin rendah.

2. Untuk menganalisis semakin tinggi rasio solvabilitas, akan memungkinkan perusahaan untuk mengalami financial distress semakin tinggi.

3. Untuk menganalisis semakin tinggi rasio profitabilitas, akan memungkinkan perusahaan untuk mengalami financial distress semakin rendah.

4. Untuk menganalisis semakin tinggi rasio pasar, akan memungkinkan perusahaan untuk mengalami financial distress semakin rendah.

\section{REVIEW LITERATUR DAN HIPOTESIS}

\section{Landasan Teori}

1. Rasio Likuiditas

Rasio ini menggambarkan kemampuan perusahaan memenuhi kewajiban jangka pendeknya, missal membayar gaji, membayar biaya operasional, membayar utang jangka pendek, membayar bahan baku dan lain sebagainya yang membutuhkan pembayaran segera atau telah jatuh tempo (Yamit, 2000). Rasio yang mengukur likuiditas jangka pendek perusahaan dengan melibatkan besarnya aktiva lancar relatif terhadap utang lancar (Hanafi 2004).

2. Rasio Solvabilitas

Rasio ini mengukur kemampuan perusahaan memenuhi kewajiban jangka panjangnya (Hanafi, 2004). Perusahaan yang tidak solvabel adalah perusahaan yang total utangnya lebih besar dibanding total asetnya. Rasio memfokuskan pada sisi kanan atau kewajiban perusahaan.

3. Rasio Profitabilitas

Rasio ini mengukur kemampuan perusahaan menghasilkan keuntungan atau profitabilitas pada tingkat penjualan, asset, dan modal saham tertentu (Hanafi, 2004).

\section{Rasio Pasar}

Rasio ini mengukur harga pasar saham perusahaan relatif terhadap nilai buku (Hanafi, 2004).

\section{Financial Distress}

Financial distress merupakan kondisi dimana keuangan perusahaan dalam keadaan tidak sehat atau kritis. Financial distressadalah keadaan suatu perusahaan yang sedang mengalami kesulitan dalam sistem keuangan yang belum terjadi kebangkrutan (Almalia, 2003).

\section{Penelitian Terdahulu}

Penelitian yang dilakukan oleh Luciana Spica Almalia dan Kristijadi, pada tahun 2003, dengan judul analisis rasio keuangan untuk memprediksi kondisi finansial distress perusahaan manufaktur yang terdaftar di Bursa Efek Jakarta periode tahun 1998-2001. Dalam penelitian ini dibentuk 12 persamaan regresi logit. Sampel penelitian ini terdiri dari 24 perusahaan marabahaya dan 37 non-distress perusahaan, hal ini dipilih secara purposive sampling. Metode statistik yang digunakan untuk menguji hipotesisi penelitian ini adalah logistik 
regresi. Hasil penelitian menunjukkan bahwa rasio profit margin (laba bersih/penjualan bersih), rasio leverage (kewajiban lancar/total aktiva), rasio likuiditas (aktiva lancar/kewajiban lancar) dan pertumbuhan (laba bersih/total aktiva pertumbuhan) adalah variabel yang signifikan terhadap menentukan perusahaan kesulitan keuangan.

Penelitian yang dilakukan oleh Ahmad (2012), menganalisis beberapa penyebab perusahaan mengalami financial distress dengan menggunakan financial ratio dan management capability sebagai prediktor. Sampel yang digunakan dalam penelitian tersebut adalah perusahaan manufaktur yang terdaftar di Bursa Efek Indonesia (BEI) selama periode 2005-2010. Hasil penelitian menyatakan bahwa rasio leverage mempunyai hubungan positif terhadap prediksi perusahaan yang sedang mengalami financial distress, sedangkan variabel-variabel yang lainnya seperti CR, TATO, CATO, ROE, ROA, WCTA, dan management capability mempunyai hubungan negatif dalam mempengaruhi prediksi financial distress di suatu perusahaan.

\section{Hipotesis}

H1: Semakin tinggi rasio likuiditas, maka kemungkinan perusahaan untuk mengalami financial distress semakin rendah dan signifikan.

$\mathrm{H} 2$ : Semakin tinggi rasio solvabilitas, maka kemungkinan perusahaan untuk mengalami financial distress semakin tinggi dan signifikan.

H3: Semakin tinggi rasio profitabilitas, maka kemungkinan perusahaan untuk mengalami financial distress semakin rendah dan signifikan.

H4: Semakin tinggi rasio pasar, maka kemungkinan perusahaan untuk mengalami financial distress semakin rendah dan signifikan.

\section{METODE PENELITIAN}

\section{Populasi dan Sampel}

Populasi penelitian ini adalah perusahaan-perusahaan manufaktur yang terdaftar di Bursa Efek Indonesia (BEI) pada periode 2011-2014. Metode yang digunakan dalam pengambilan sampel ini menggunakan purposive sampling. Purposive sampling yaitu metode pengambilan sampel dengan menggunakan beberapa pemilihan sesuai dengan kriteria. Dengan tujuan untuk mendapatkan sampel yang representative sesuai dengan kriteria yang telah ditentukan Nur Indriantoro dan Bambang Supomo, (1999) dalam Luciana (2003).

Beberapa kriteria yang ditetapkan dalam pengambilan sampel penelitian ini adalah sebagai berikut (Platt, 2002):

1. Perusahaan selama dua tahun berturutturut mengalami laba bersih positif.

2. Perusahaan selama dua tahun berturut-turut mengalami laba bersih negatif, yang diartikan perusahaan mengalami kerugian dan perusahaan menanggung beban hutang yang sangat besar dari modal sendiri maupun modal asing.

Data laporan keuangan tahun 20132014 digunakan sebagai pedoman penentu apakah suatu perusahaan mengalami financial distress atau tidak. Sedangkan data laporan keuangan tahun 2011-2012 merupakan data yang akan di olah.

\section{Definisi Operasional}

1. Variabel Independen

a. Rasio Likuiditas

Rasio ini menggambarkan kemampuan perusahaan memenuhi kewajiban jangka pendeknya, misal membayar gaji, membayar biaya operasional, membayar utang jangka pendek, membayar biaya bahan baku dan lain sebagainya yang membutuhkan pembayaran segera atau telah jatuh tempo (Yamit, 
2000). Rasio yang mengukur likuiditas jangka pendek perusahaan dengan melibatkan besarnya aktiva lancar relatif terhadap utang lancarnya. Utang dalam hal ini merupakan kewajiban perusahaan (Hanafi, 2004). Alat yang digunakan untuk menghitung rasio ini menggunakan proksi sebagai berikut:

\section{Rasio Lancar $=$ Aktiva Lancar $\overline{\text { Utang Lancar }}$}

b. Rasio Solvabilitas

$$
\text { Rasio ini mengukur }
$$
kemampuan perusahaan memenuhi kewajiban jangka panjangnya. Perusahaan yang tidak solvabel adalah perusahaan yang total utangnya lebih besar dibandingkan dengan total assetnya. Rasio memfokuskan pada sisi kanan atau kewajiban perusahaan (Hanafi, 2004). Untuk menghitung rasio ini dapat digunakan sebagai berikut:

Total Utang terhadap Total Aset $=\frac{\text { Total Utang }}{\text { Total asset }}$

c. Rasio Profitabilitas

$$
\text { Rasio ini mengukur }
$$

kemampuan perusahaan

menghasilkan keuntungan atau profitabilitas pada tingakat penjualan, asset, dan modal saham tertentu. Profit margin menghitung sejauh mana kemampuan perusahaan menghasilkan laba bersih pada tingkat penjualan tertentu (Hanafi, 2004). Rasio ini bisa dicari dengan menggunakan persamaan berikut:

\section{Profit Margin $=\quad \frac{\text { Laba bersih }}{\text { Penjualan }}$}

d. Rasio Pasar

Rasio ini mengukur harga pasar saham relatif terhadap nilai buku. Sudut pandang rasio ini lebih banyak pada investor ataupun calon investor meski pihak manajemen juga berkepentingan terhadap rasio ini (Hanafi,2004).
Untuk menghitung ini bisa menggunakan cara sebagai berikut:

$$
\text { PER }=\text { Harga Pasar per lembar }
$$$$
\text { Earning per Lembar }
$$

2. Variabel Dependen

Variabel dependen atau tidak bebas merupakan variabel yang dijelaskan atau dipengaruhi oleh variabel independen (Rahmawati, 2008). Sebagai variabel dependen dalam penelitian ini adalah kondisi financial distress, yang merupakan variabel kategori 1 untuk perusahaanperusahaan tidak sehat (mengalami financial distress) dan 0 untuk perusahaan sehat (tidak mengalami financial distress) (Platt, 2002). Pada variabel dependen ini periode waktunya memakai $t$ (waktu sekarang) sebagai bahan yang di olah. Variabel kondisi financial distress merupakan variable katagori 0 sampai 1 (Platt, 2002), yaitu:

a. Angka 0 untuk mewakili perusahaan sehat, perusahaan yang tidak mengalami kondisi financial distress, yaitu perusahaan yang selama dua tahun berturut-turut mengalami laba bersih positif.

b. Angka 1 untuk mewakili perusahaan yang mengalami kondisi financial distress, yaitu perusahaan yang selama dua tahun berturutturut mengalami laba bersih negatif.

\section{Uji Instrumen}

\section{Uji Validitas}

a. Normalitas

Uji normalitas bertujuan untuk menguji dalam model regresi, variabel dependen, variabel independen atau keduanya mempunyai ditribusi normal, atau tidak mempunyai distribusi normal. Pada penelitian ini menggunakan uji statistik Jarque-Bera dengan menggunakan software eviews dengan pengambilan keputusan 
jika nilai signifikansi atau probabilitas $\mathrm{J}-\mathrm{B}<0,05$ maka distribusi data adalah tidak normal. Jika nilai signifikansi atau probabilitas J-B > 0,05 maka distribusi data adalah normal (Kusuma, 2012).

b. Autokorelasi

Pengujian ini bertujuan untuk mengetahui hubungan antara satu observasi dengan observasi lainnya. Setiap data residual pada suatu observasi diharapkan saling bebas dengan observasi lannya atau tidak ada autokorelasi. Penelitian ini menggunakan uji durbin Watson dan menggunakan software eviews untuk mengetahui ada atau tidak autokorelasi dengan ketentuan sebagai berikut (Kusuma, 2012).

Table DW Test

\begin{tabular}{|l|c|c|}
\hline \multicolumn{1}{|c|}{ Hipotesis Nol } & Keputusan & Jika \\
\hline $\begin{array}{l}\text { Tidak ada autokorelasi } \\
\text { positif }\end{array}$ & Tolak & $0<\mathrm{d}<\mathrm{dl}$ \\
\hline $\begin{array}{l}\text { Tidak ada autokorelasi } \\
\text { positif }\end{array}$ & Tidak ada keputusan & $\mathrm{dl} \leq \mathrm{d} \leq \mathrm{du}$ \\
\hline $\begin{array}{l}\text { Tidak ada autokorelasi } \\
\text { positif }\end{array}$ & Tolak & $4-\mathrm{dl}<\mathrm{d}<<4$ \\
\hline $\begin{array}{l}\text { Tidak ada autokorelasi } \\
\text { positif }\end{array}$ & Tidak ada keputusan & $4-\mathrm{du} \leq \mathrm{d} \leq 4-\mathrm{dl}$ \\
\hline $\begin{array}{l}\text { Tidak ada autokorelasi } \\
\text { positif atau negative }\end{array}$ & Tidak ditolak & $\mathrm{du}<\mathrm{d}<4-\mathrm{du}$ \\
\hline
\end{tabular}

c. Heteroskedastisitas

Pengujian ini bertujuan untuk menguji apakah dalam model regresi terjadi ketidaksamaan variance dari residual satu pengamatan kepengamatan lain. Jika variance dari residual satu pengamatan kepengamatan lain tetap, maka disebut homoskedastisitas, dan jika berbeda disebut heteroskedastisitas. Alat analisis yang digunakan dalam pengujian ini menggunakan Uji White dan Uji BPG (BreushPagan-Godfrey). Pengambilan keputusan pada penelitian ini yaitu, jika pada pengujian nilai Prob. Chi Square pada Obs*R-squared < 0,05 maka menunjukkan terjadinya heteroskedastisitas, sedangkan jika nilai Prob. Chi Square pada Obs*Rsquared > 0,05 maka tidak terjadi heteroskedastisitas (Kusuma, 2012).

d. Multikolinieritas

Multikolinearitas artinya antara independen variabel yang terdapat dalam model memiliki hubungan yang sempurna atau mendekati sempurna (koefisien korelasinya tinggi atau $=1$ ). Uji multikolinearitas bertujuan untuk menguji apakah model regresi ditemukan regresi antar variabel bebas (independen).Analisis untuk mendeteksi ada atau tidaknya multikolonieritas di dalam model regresi sebagai berikut:

a. Melihat $t$ hitung, $\mathrm{R} 2$ dan $\mathrm{F}$ ratio. Jika $\mathrm{R} 2$ tinggi, nilai $\mathrm{F} 2$ tinggi, sedangkaan sebagian besar atau seluruh koefisien regresi tidak signifikan (nilai $\mathrm{t}$ hitung sangat rendah).

b. Menentukan koefisiansi kolerasi antara independen variabel yang satu dengan independen variabel yang lain. Jika antara dua variabel independen memiliki korelasi yang spesifik maka didalam regresi terdapat multikolonieritas.

c. Melakukan regresi auxiliary, meregresikan antar variabel independen. Salah satu variabel independen digunakan sebagai variabel dependen kemudian diregresikan dengan variabel independen yang lainnya. Jika nilai prop. dari $\mathrm{F}$ statistik lebih kecil dari a 5\% maka terjadi multikolinearitas.

\section{Teknik Analisis Data}

Alat analisis yang digunakan dalam penelitian ini adalah regresi logit dan menggunakan software eviews. Regresi logit untuk mengetahui kekuatan prediksi rasio keuangan terhadap penentuan 
financial distress suatu perusahaan. (Lusiana, 2003).

Teknik statistik ini digunakan untuk mengetahui pengaruh satu variabel independen atau lebih (X) terhadap satu variabel dependen (Y), dengan syarat:

1. Variabel dependen harus merupakan variabel dummy yang hanya punya dua alternatif. Misalnya perusahaan sehat dan tidak sehat, dimana jika perusahaan sehat kita beri angka 0 dan jika perusahaan tidak sehat kita beri angka 1.

2. Variabel independen mempunyai skala data interval atau rasio.

$\mathrm{P}_{\mathrm{i}}=1 /\{1+\mathrm{Exp}-(\mathrm{B} 0+\mathrm{B} 1 \mathrm{X} 1+\mathrm{B} 2 \mathrm{X} 2$ $+\mathrm{B} 3 \mathrm{X} 3+\mathrm{B} 4 \mathrm{X} 4)\}$

Dimana :

$\mathrm{P}_{\mathrm{i}}=$ Probabilitas perusahaan mengalami financial distress

$\mathrm{B} 0-\mathrm{B} 4=$ Koefisien persamaan regresi

$\mathrm{X} 1=$ Rasio likuiditas

$\mathrm{X} 2$ = Rasio solvabilitas

X3 = Rasio profitabilitas

$\mathrm{X} 4=$ Rasio pasar

$\operatorname{Exp}=$ Kesalahan yang mempunyai nilai pengharapan sebesar nol.

Pada penelitian ini tingkat signifikan $(\alpha)=1 \%, 5 \%, 10 \%$ maka Ha diterima jika nilai sign $<1 \%, 5 \%$, $10 \%$ dan Ha ditolak jika nilai sign $>1 \%$, $5 \%, 10 \%$.

Regresi logistik memiliki fungsi logit yang berhubungan yaitu regresi logistik menghitung perubahan dalam (log odds) dari variabel dependen, bukan dari perubahan variabel dependen itu sendiri. Beberapa istilah prinsip dan konsep yang dipakai dalam regresi logit yang dipakai untuk memahami dalam penelitian ini adalah (Ghozali, 2001) :

a. Koefisien Logit (B)

Koefisien logit juga disebut koefisien logistik yang tidak distrandarisasi, yaitu koefisien yang berfungsi sebagai faktor perimbangan untuk variabel independen dalam hubungan kekuatan diskriminatif. Logit adalah log natural dari odds, yang dipakai dalam persamaan logistik untuk memprediksi log odds bahwa variabel dependen adalah sama dengan 1 (regresi logistik binomial).

b. Rasio Odds (Exp/B)

Rasio Odds adalah perbandingan antara kemungkinan suatu hal dengan kemungkinan hal yang tidak terjadi yang digunakan sebagai variabel dependen. Logit dapat diubah dalam pernyataan tentang rasio odds variabel dependen hanya menggunakan fungsi exponent. Sebagai contoh jika logit $\mathrm{b}, \log$ odds adalah fungsi exponent eb, bisa dipahami sebagai berikut : jika variabel independen naik 1 unit, odds dari variabel dependen 1 akan naik oleh faktor eb, ketika variabel lain diatur.

c. Statistik Wald

Statistik wald adalah tes yang digunakan dalam regresi logistik untuk menguji tingkat koefisien logistik. Model ini biasanya untuk menguji tingkat koefisien regresi logistik individual bagi setiap variabel independen, yaitu untuk menguji hipotesa nol dalam regresi logistik dalam koefisien logitnya nol ini adalah rasio dari koefisien logit yang tidak standar terhadap standar kesalahan, namun kita biasanya melihat tingkat manfaat yang berhubungan dari pada statistik wald sendiri.

\section{HASIL PENELITIAN DAN PEMBAHASAN}

\section{Hasil Penelitian}

1. Hasil Uji Asumsi Klasik

a. Normalitas

Hasil Pengujian Normalitas

\begin{tabular}{|l|l|l|l|l|l|}
\hline & $\mathrm{X} 1$ & $\mathrm{X} 2$ & $\mathrm{X} 3$ & $\mathrm{X} 4$ & $\mathrm{Y}$ \\
\hline Jarque-Bera & 459.0689 & 2969.756 & 85915.73 & 212995.7 & 144.0954 \\
\hline Probability & 0.000000 & 0.000000 & 0.000000 & 0.000000 & 0.000000 \\
\hline
\end{tabular}

Berdasarkan tabel di atas menunjukkan bahwa variable $\mathrm{X} 1$, $\mathrm{X} 2, \mathrm{X} 3, \mathrm{X} 4$ dan $\mathrm{Y}$ mempunyai data berdistribusi tidak normal, karena masing- masing nilai probabilitas $\mathrm{J}$ $\mathrm{B}<0,05$. 
Pengujian Distribusi Residual Regresi

\begin{tabular}{|c|c|}
\hline Jarque-Bera & 145.9757 \\
\hline Probability & 0.000000 \\
\hline
\end{tabular}

Berdasarkan tabel di atas menunjukkan bahwa residual persamaan regresi berdistribusi tidak normal. Hal ini ditunjukkan pada nilai probabilitas $\mathrm{J}-\mathrm{B}$ yang sebesar 0,000 , yang mana lebih kecil dari 0,05 .

b. Autokorelasi

Hasil Pengujian Autokorelasi

\begin{tabular}{|l|l|l|l|}
\hline R-squared & 0.161793 & Mean dependent var & 0.150538 \\
\hline Adjusted R-squared & 0.143269 & S.D. dependent var & 0.358563 \\
\hline S.E. of regression & 0.331885 & Akaike info criterion & 0.658456 \\
\hline Sum squared resid & 19.93670 & Schwarz criterion & 0.745170 \\
\hline Log likelihood & -56.23643 & Hannan-Quinn criter. & 0.693596 \\
\hline F-statistic & 8.734290 & Durbin-Watson stat & 0.384786 \\
\hline Prob(F-statistic) & 0.000002 & & \\
\hline
\end{tabular}

Berdasarkan tabel di atas menunjukkan bahwa nilai DurbinWatson stat adalah 0,384. Selanjutnya mencari tabel D-W, yaitu dengan $\mathrm{n}=186$ dan $\mathrm{k}=4$ diperoleh nilai $\mathrm{dL}=1,716$ dan $\mathrm{dU}=1,804$. Maka dapat disimpulkan $0<0,384<1,716$ atau terjadi autokorelasi.

c. Heteroskedastisitas

Hasil Uji White

\begin{tabular}{|l|l|l|l|}
\hline F-statistic & 2.338432 & Prob. F(14,171) & 0.0056 \\
\hline Obs*R-squared & 29.88777 & Prob. Chi-Square(14) & 0.0079 \\
\hline Scaled explained SS & 61.00687 & Prob. Chi-Square(14) & 0.0000 \\
\hline
\end{tabular}

Berdasarkan tabel di atas menunjukkan bahwa nilai Prob. Chi Square pada Obs*R-square 0,007 < 0,05 . Jadi dapat disimpulkan ada masalah heteroskedastisitas.

Hasil Uji BPG

\begin{tabular}{|l|l|l|l|}
\hline F-statistic & 3.030605 & Prob. F(4,181) & 0.0189 \\
\hline Obs*R-squared & 11.67534 & Prob. Chi-Square(4) & 0.0199 \\
\hline Scaled explained SS & 23.83169 & Prob. Chi-Square(4) & 0.0001 \\
\hline
\end{tabular}

Berdasarkan tabel di atas menunjukkan bahwa nilai Prob. Chi Square pada Obs*R-square $0,019<0,05$. Jadi dapat disimpulkan ada masalah heteroskedastisitas.

d. Multikolinieritas

Hasil Pengujian Multikolinearitas

\begin{tabular}{|c|c|c|c|c|}
\hline & $\mathrm{X} 1$ & $\mathrm{X} 2$ & $\mathrm{X} 3$ & $\mathrm{X} 4$ \\
\hline $\mathrm{X} 1$ & 1.000000 & -0.186104 & 0.002853 & -0.049900 \\
\hline $\mathrm{X} 2$ & -0.186104 & 1.000000 & -0.105856 & 0.002665 \\
\hline $\mathrm{X} 3$ & 0.002853 & -0.105856 & 1.000000 & -0.014340 \\
\hline $\mathrm{X} 4$ & -0.049900 & 0.002665 & -0.014340 & 1.000000 \\
\hline
\end{tabular}

Berdasarkan tabel di atas menunjukkan bahwa nilai korelasi antar variable independen $<90 \%$. Hal ini menunjukkan bahwa tidak terjadi hubungan linier antar variabel independen dalam model regresi tersebut.

2. Hasil Uji Regresi Logit

Hasil Pengujian Regresi Logit

\begin{tabular}{|c|c|c|c|c|}
\hline Variable & Coefficient & Std. Error & z-Statistic & Prob. \\
\hline $\mathrm{C}$ & -2.644571 & 0.482259 & -5.483714 & 0.0000 \\
\hline $\mathrm{X} 1$ & -0.262014 & 0.151164 & -1.733316 & 0.0830 \\
\hline $\mathrm{X} 2$ & 2.532228 & 0.731632 & 3.461066 & 0.0005 \\
\hline $\mathrm{X} 3$ & -0.229730 & 0.344925 & -0.666029 & 0.5054 \\
\hline $\mathrm{X} 4$ & -0.001061 & 0.003020 & -0.351291 & 0.7254 \\
\hline
\end{tabular}

$P_{i}=-2,644-0,262 X 1+2,532 \times 2-0,229 \times 3-0,001 X 4$

Keterangan:

a. Nilai Ods dari konstanta sebesar 0,070 yang berarti bahwa, jika variabel rasio likuiditas, rasio solvabilitas, rasio profitabilitas dan rasio pasar perusahaan dianggap konstan maka nilai financial distress sebesar 0,070.

b. Nilai Ods Ratio dari rasio likuiditas (X1) sebesar 0,769 menyatakan bahwa setiap penambahan rasio likuiditas sebesar 1 akan menurunkan kecenderungan perusahaan mengalami financial distress sebesar 0,769 dan sebaliknya.

c. Nilai Ods Ratio dari rasio solvabilitas (X2) sebesar 12,589 menyatakan bahwa setiap penambahan rasio solvabilitas sebesar 1 akan meningkatkan kecenderungan perusahaan 
mengalami financial distress sebesar 12,589 dan sebaliknya.

d. Nilai Ods Ratio dari rasio profitabilitas (X3) sebesar 0,795 menyatakan bahwa setiap penambahan rasio profitabilitas sebesar 1 akan menurunkan kecenderungan perusahaan mengalami financial distress sebesar 0,795 dan sebaliknya.

e. Nilai Ods Ratio dari rasio pasar (X4) sebesar 0,999 menyatakan bahwa setiap penambahan rasio pasar sebesar 1 akan menurunkan kecenderungan perusahaan mengalami financial distress sebesar 0,999 dan sebaliknya.

3. Hasil Pengujian Hipotesis

a. Pengujian Hipotesis Pertama (H1)

Hasil pengujian untuk variabel rasio likuiditas memiliki koefisien regresi sebesar $-0,262$ dan nilai probabilitas sebesar $0,083<0,10$. Hal ini berarti hipotesis pertama diterima. Hasil penelitian menunjukkan bahwa semakin tinggi rasio likuiditas, maka kemungkinan perusahaan untuk mengalami financial distress semakin rendah dan signifikan pada tingkat $10 \%$.

b. Pengujian Hipotesis Kedua (H2)

Hasil pengujian untuk variabel rasio solvabilitas memiliki koefisien regresi sebesar 2,532 dan nilai probabilitas sebesar $0,000<0,01$. Hal ini berarti hipotesis kedua diterima. Hasil penelitian menunjukkan bahwa semakin tinggi rasio solvabilitas, maka kemungkinan perusahaan untuk mengalami financial distress semakin tinggi dan signifikan pada tingkat $1 \%, 5 \%$ dan $10 \%$. c. Pengujian Hipotesis Ketiga (H3)

Hasil pengujian untuk variabel rasio profitabilitas memiliki koefisien regresi sebesar $-0,299$ dan nilai probabilitas sebesar $0,505>$ 0,10 . Hal ini berarti hipotesis ketiga ditolak. Hasil penelitian menunjukkan bahwa semakin tinggi rasio profitabilitas, maka kemungkinan perusahaan untuk mengalami financial distress semakin rendah dan tidak signifikan.

d. Pengujian Hipotesis Keempat (H4)

Hasil pengujian untuk variable rasio pasar memiliki koefisien regresi sebesar $-0,001$ dan nilai probabilitas sebesar $0,725>0,10$. Hal ini berarti hipotesis keempat ditolak. Hasil penelitian menunjukkan bahwa semakin tinggi rasio pasar, maka kemungkinan perusahaan untuk mengalami financial distress semakin rendah dan tidak signifikan.

\section{Pembahasan}

Hasil analisis menunjukkan bahwa hipotesis pertama (H1) yaitu semakin tinggi rasio likuiditas, maka kemungkinan perusahaan untuk mengalami financial distress semakin rendah dan signifikan. Hasil penelitian ini sesuai dengan hasil penelitian Almalia (2003). Hal ini berarti semakin liquid kondisi perusahaan yang ditunjukkan dengan current ratio yang semakin besar maka kondisi financial distress akan semakin rendah. Karena semakin besar aktiva yang diperoleh perusahaan, maka semakin sedikit perusahaan menanggung hutangnya, sehingga perusahaan akan terhindar dari kesulitan keuangan.

Hasil analisis menunjukkan bahwa hipotesis kedua (H2) yaitu semakin tinggi rasio solvabilitas, maka kemungkinan perusahaan untuk mengalami financial distress semakin tinggi dan signifikan. Hasil penelitian ini 
sesuai dengan hasil penelitian Almalia (2003). Hal ini berarti semakin tinggi leverage ratio maka semakin tinggi peluang kebangkrutan atau perusahaan berpotensi mengalami financial distress. Karena semakin tinggi hutang perusahaan secara terus menerus dibandingkan aset perusahaan yang dimiliki, maka peluang perusahaan mengalami kesulitan keuangan semakin besar jika aset yang dimiliki perusahaan tidak mampu menutup hutangnya.

Hasil analisis menunjukkan bahwa hipotesis ketiga $(\mathrm{H} 3)$ yaitu semakin tinggi rasio profitabilitas, maka kemungkinan perusahaan untuk mengalami financial distress semakin rendah dan tidak signifikan. Hasil penelitian ini tidak sesuai dengan hasil penelitian Almalia (2003). Hal ini menunjukkan bahwa pertumbuhan penjualan yang tinggi belum tentu menghasilkan keuntungan yang tinggi, sehingga tidak mempunyai pengaruh terhadap financial distress sesuai dengan penelitian Wahyu Widarjo dan Doddy Setiawan (2009).

Hasil analisis menunjukkan bahwa (H4) yaitu semakin tinggi rasio pasar, maka kemungkinan perusahaan untuk mengalami financial distress semakin rendah dan tidak signifikan. Jika dilihat dari koefisien regresi yang bernilai negatif menunjukkan bahwa semakin tinggi PER semakin besar prospek perusahaan kedepan sehingga akan berpeluang kecil mengalami kebangkrutan. Rasio PER menunjukkan prospek pertumbuhan perusahaan di masa yang akan datang. Tingkat pertumbuhan laba baik jangka panjang maupun jangka pendek, merupakan cerminan berkembang tidaknya perusahaan. Tingkat PER yang rendah akan mempengaruhi kondisi keuangan. Semakin tinggi nilai PER nya semakin kesil kemungkinan terjadi financial distress.

\section{KESIMPULAN DAN SARAN}

\section{Kesimpulan}

1. Semakin tinggi rasio likuiditas, maka kemungkinan perusahaan untuk mengalami financial distress semakin rendah dan signifikan.

2. Semakin tinggi rasio solvabilitas, maka kemungkinan perusahaan untuk mengalami financial distress semakin tinggi dan signifikan.

3. Semakin tinggi rasio profitabilitas, maka kemungkinan perusahaan untuk mengalami financial distress semakin rendah tetapi tidak signifikan.

4. Semakin tinggi rasio pasar, maka kemungkinan perusahaan mengalami financial distress semakin rendah tetapi tidak signifikan.

\section{Saran}

1. Bagi pemakai informasi laporan keuangan hendaknya dalam menentukan kondisi Financial Distress hendaknya mempertimbangkan likuiditas perusahaan, profitabilitas, dan prospek pertumbuhan ke depan, karena keempat faktor tersebut cukup efektif dalam menentukan Financial Distress.

2. Memperluas penelitian dengan cara menambah periode penelitian dan memperbanyak jumlah sampel penelitian, sehingga dapat lebih bervariasi. Namun harus diperhatikan mengenai perbedaan karakter dari tiap jenis perusahaan tersebut.

3. Untuk penelitian selanjutnya sebaiknya mempertimbangkan rasio keuangan lainnya seperti posisi kas, rasio pertumbuhan, efisiensi serta faktor-faktor eksternal seperti inflasi, kurs, suku bunga dan lainnya, sehingga dapat diketahui secara lebih luas faktor-faktor apa saja yang berpengaruh terhadap kondisi Financial Distress perusahaan. 


\section{DAFTAR PUSTAKA}

Almalia, Luciana Spica, dan Kristijadi. (2003). "Analisis Rasio Keuangan untuk Memprediksi Kondisi Financial Distress Perusahaan Manufaktur yang terdaftar di BEJ". Jurnal Akuntansi dan Auditing Indonesia (Desember), hal.183-206.

Almalia, Luciana Spica. (2006). "Prediksi Kondisi Financial Dostress Perusahaan Go Publik Dengan Menggunakan Analisis Multinomial Logit". Jurnal Ekonomi Bisnis (Maret).

Ardina. (2013). "Pengaruh Efektivitas Komite Audit Terhadap Financial Distress". Universitas Diponegoro.

Arif, Hidayat Muhammad. (2013). Prediksi Financial Distress Perusahaan Manufaktur Di Indonesia. Skripsi. Universitas Diponegoro.

Fraster, L.M dan Ormiston A. (2008). Memahami Laporan Keuangan. Edisi 7. Jakarta: PT. Inteks.

Ghozali, Imam. (2001). Aplikasi Multivariate Dengan Program IMB SPSS 19. Edisi 5. Semarang: Universitas Diponegoro.

Hanafi, Mamduh M. (2004). Manajemen Keuangan. Yogyakarta: Universitas Gadjah Mada Yogyakarta, UPFE.

Kusuma, Desta Risky dan Deny Ismanto. (2012). Modul Praktikum Eviews. Yogyakarta: Universitas Ahmad Dahlan.

Munawir S. (2002). Analisis Informasi Keuangan. Yogyakarta: Universitas Gajah Mada, UPFE.

Rahmawati, Alni, dkk. (2008). Modul Statistik II. Yogyakarta: Fakultas
Ekonomi

Universitas

Muhammadiyah Yogyakarta UPFE. Suroso. (2006). Investasi Pada Saham Perusahaan yang Menghadapi Financial Distress. Usahawan. 